\title{
English Syllabus Change on the Basis of School Based Curriculum Development within the Context of a Western Mexican University
}

\author{
Fernando Manuel Peralta Castro ${ }^{1, *}$ \\ ${ }^{1}$ School of Foreign Languages, Universidad de Colima, Mexico \\ *Correspondence: School of Foreign Languages, Universidad de Colima, Mexico. E-mail: peralta@ucol.mx
}

Received: September 7, 2017

Accepted: September 21, 2017 Online Published: Sptember 27, 2017

doi:10.5430/wjel.v7n3p40

URL: https://doi.org/10.5430/wjel.v7n3p40

\begin{abstract}
This study aims to investigate the process of improving the English language syllabus within the context of a Western University in Mexico. It was an Action Research investigation which involved the participation of a group of teachers, who played a predominant role during the research, evaluating the original syllabus, producing descriptions resulting in a detailed characterization of it. They also designed a new syllabus, and finally they evaluated the process of improving it. Findings of the study demonstrate that language teachers engaged in a process of analysis and reflection are led to make decisions and changes based on local needs. Findings also demonstrate that, even when teachers showed the greatest willingness to participate in the study they also faced serious challenges.
\end{abstract}

Keywords: school based curriculum development; English language teaching in Mexico; syllabus design

\section{Introduction}

This paper presents the results of a study of a group of Mexican language teachers who changed the syllabus they used, following a School Based Curriculum Development (SBCD), which claims that centrally based curriculum developers do not take into account those key elements characteristic of the context, which in many occasions represent the diverse needs of students and teachers, and hinder the success of any curriculum improvement initiative (Marsh, 2009).

The article presents a short overview of the situation of ELT in Mexico, and criticizes the syllabus design approach coming from top to bottom, as well as the import of ELT approaches conceived for Britain, Australasia, and North America (BANA) countries. This is followed by a brief definition of SBCD. Next, the paper provides some details of the research methodology. Then an analysis of the syllabus and an examination of the process of syllabus change on the basis of Needs Analysis (NA) findings are shown.

The findings make an emphasis on the importance of NA in the process of syllabus change, and gives details of how the data emerging from the teaching context helps language teachers understand students' language learning needs, and also recognize the importance of critical reflection upon the process of syllabus design. Teachers also realise the significance of gathering data from different sources, as well as the relevance of data processing and systematization. The challenges that syllabus design represent for language teachers are also shown.

\section{English the Main Foreign Language Taught in Mexico}

English language has been the main foreign language taught within the educational system in Mexico in both lower secondary and upper secondary education (Davies, 2009), and after 2008 was included as a subject in the curriculum of preschool and elementary education, as well. The ELT syllabuses in Mexico are devised based on the alignment and standardization of national and international standards, the selection of criteria for teacher training, the establishment of guidelines for the design and evaluation of educational materials, as well as for the certification of English language proficiency (Secretaría de Educación Pública, 2010).

Several Mexican universities have incorporated English as a compulsory subject across their curriculum. The aim of their language courses is that students develop a good working command of English so that they have increased 
access to updated information to be able to be hired by multinational organizations, which their lingua franca is English, to be able to participate in international conferences, and to travel abroad to take postgraduate courses (Davies, 2008). In most universities English courses start at a false beginner level and the great majority of the students are in beginner, elementary and lower intermediate courses (Davies, 2008). The way they organize language teaching varies from one institution to another. Many require all students to finish a given number of English courses, usually with no reliable evaluation of their level of proficiency at the end. Some require their students to pass an English proficiency test to be able to graduate. Each university organizes its own English language syllabus, which in most cases arises from an institutional policy, from top to bottom; aligning their ELT policy with international bodies, such as UNESCO, which explicitly recommends the teaching of second languages, giving particular emphasis to the learning of English as the 'dominant language of scientific communication' (UNESCO, 2009, p. iv). Besides following the recommendations of international bodies, approaches, principles, methods, materials conceived for BANA countries are mainly adopted.

Both organising a syllabus from top to bottom following ELT international policies, and importing approaches conceived for BANA countries may have shortcomings. Organinsing the syllabus from top to bottom is similar to approaching it from a specialist approach defining from the top what is to be taught and 'teachers through instruction, implement the plan' (Graves, 2008, p. 149). One of the problems with the specialist approach to language curriculum is that there is a mismatch between the domains, policy makers, syllabus designers, teachers and learners as they perform different curriculum functions, use different discourse, and produce different curriculum products (Graves, 2008).

An example of specialist approach has been provided by O'Sullivan (2002) who gives details of the results of a three-year research study in Namibia. The researcher investigated the implications of the reform policies for English language teaching developed by the ministry of education. The policy stated that subject in senior primary should be taught in English. Functional English syllabuses were also developed. Some other principles in regards to English language teaching were also stated to be implemented in the classroom such as, learner-centred and communicative approaches to ELT, pair and group work and so on. The researcher reports that the reforms were significantly beyond the capacity of the teachers participating in the research; as evidence provides a number of both subjective and objective factors rooted in the classroom, which inhibited the effective implementation of the reforms.

ELT in BANA countries is mainly instrumentally (Holliday, 1994) and it is not possible for such conceptions to have universal application due to local constraints (Ahmad \& Sajjad, 2011). For instance, Nunan (2003) presents the results of an investigation into the place of English in the curriculum in several countries in the Asia-Pacific region. The study indicates that the emergence of English as a global language is having a considerable impact on policies and practices in all countries surveyed. However, it also reveals significant problems, for instance: teachers are inadequately trained in language teaching methodology, teachers' own language skills are poor, classrooms realities do not meet curriculum rhetoric, and students do not have sufficient exposure to English in instructional contexts. Research is needed on the English language requirements of workers in workplaces and occupations. The study demonstrates that simple ELT policies embedded into the curriculum of a country, or an educational institution does not necessarily guaranteed successful language learning and teaching.

The problem with ELT syllabuses prescribed from top to bottom is that the classroom is put at the end of the chain of decisions, (...) it positions teachers -and learners- as recipients and implementers of received wisdom, rather than decision-makers in their own right. (...) there is usually no room for valuation of the curriculum once it is implemented in the classroom. (Graves, 2008, p. 150-151). But the separation between the people, the process and the products generates a gap between the teaching language policy issued and the attempt to operationalize them (Stenhouse, 1975).

\section{School Based Curriculum Development}

An ecological approach to syllabus development which highlights features such as common decisions made by teachers and students is School Based Curriculum Development (SBCD) (Skilbeck, 1984). Accordingly SBCD is the opposite to specialist approach to curriculum, and advocates the participation of teachers in the design and development of curriculum materials within a particular school (Marsh, Day, Hannay, and McCutcheon, 1990). SBCD can be seen as a response to hierarchical or centrally based curriculum development. SBCD advocates that centrally based curriculum developers do not take into account the different needs of students and teachers in a particular teaching context. Top-down modes of curriculum development ignore classroom teachers and provide them with little incentive, involvement, and job satisfaction. SBCD advocates argue that centrally based curriculums 
do not take into account those key elements characteristic of the context, which in many occasions represent the diverse needs of students and teachers, and hinder the success of any curriculum improvement initiative (Marsh, 2009). In SBCD teachers, as curriculum developers, play a predominant role as they do not only apply the knowledge gained by expertise, but generate their own theories supported by their experience and practice. This is vital as they know the classroom situations better than anybody and can thereby make a unique contribution to the success of the curriculum (Al-Daami \& Stanley, 1998).

Connelly \& Ben-Perez (1980) provide the rational for teacher participation in curriculum planning and development and states: 'Because of their involvement in classroom situations, the role of the teacher is crucial for discovering the apparent gaps and bringing about change or improvement. Teachers have intimate knowledge of learners, classroom and school milieu. This knowledge allows teachers to point out weaknesses [and] shortcomings (...)' (p. 54).

\section{The Study}

The study was conducted within a Higher Education Institution in Western Mexico. The faculty of Economics was chosen as it has a long-established history of teaching languages, as well as many other faculties. The aim of the study was to investigate the process of improving the language syllabus at the faculty of Economics.

Language teachers who participated in the study were selected on the basis of their ability to provide rich and varied insights into the research problem under investigation. In other words they were purposeful or purposive selected (Dörnyei, 2007). They shared important knowledge of the teaching situation, which contributed to maximizing what can be learnt throughout the study.

The researcher stood with and alongside the group of teachers, not outside as an objective observer or external consultant. His role as researcher and teacher provided a unique possibility to explore the social and cultural context in which teaching is delivered. The active involvement of the researcher was not a threat, but something that produced more insight. Although most of the decisions about the study were taken as a group, which implied that teacher participants were critically involved in the decision making process, the project continued to be a research, which implied that participants' involvement was on a voluntary basis, and it was made clear that they could withdraw from the study at any time.

The teachers played a predominant role during the research; they participated at different moments of the process. First, they evaluated the original syllabus producing descriptions resulting in a detailed characterization of it. Second, they designed a new syllabus, and finally they evaluated the process of improving the syllabus.

Besides capturing teachers' reflections, attitudes, beliefs, points of view, the study also conducted different NA, such as the analysis of learners' communicative language needs, which according to Srabua (2007) it helps gather appropriate data to serve as the basis for developing successful language courses. A recurring means of investigating learners' communicative needs, what learners know or do not know about the language, has been language tests (Wozniak, 2010). However, Prince (1984) claims that the language teaching approach for occupational purpose courses is not only goal-oriented, but process-oriented as well; therefore it is necessary to use different techniques. Consequently, the analysis of the language features needed to communicate in a target situation "will alone clearly be insufficient' (Long, 2005, p. 2) to determine the different needs a target group has. Thus one single approach to NA is not enough to understand the range of circumstances that surround a language teaching situation at the school level. Another technique that would be suited to finding out about the target situation is interviews with participants, potential employers, to gain an insight into their perspectives on the needs of the target situation (Cowling, 2007).

NA attempts to document the design and development process through the knowledge and views of local participants, since retaining a merely linguistic approach to the teaching target situation seems to be very simplistic and will only reveal a partial view of the situation (Cowling, 2007). For that reason, it is appropriate to explore other approaches to establish a position regarding the most suitable one for the context. For example, considering the beliefs and opinions of language learners, strategic participants of learning and teaching, and taking their opinions into account accordingly before making any decisions about teaching appears reasonable, especially if the approach to curriculum design is school-based, as learners' beliefs about language learning might influence their performance. This has been acknowledged by (Mori, 1999; Ariogul, Unal, and Onursal, , 2009; Trinder, 2013). The means by which the beliefs and opinions of language learners was gathered was through a questionnaire.

Investigating particular characteristics of the teaching context influencing the life of participants such as to resources, institutional politics, social and economic conditions is also necessary as these factors could define the outcomes of a language course (Holliday, 1995). This was shown by Le Ha (2004) by demonstrating that even though local 
pedagogical practices may seem odd in the eyes of Western teaching principles, they take account of the cultural context of the classroom. The investigation of the context can through interviews with members of the school and of course language teachers. Interviews provide a good description of the context, as well as their opinions and beliefs the teaching situation; as interviews are ' $(. .$.$) means of pure information transfer' (Cohen, Manion, and Morrison,$ 2011, p. 409).

\section{An Evaluation of the Original Syllabus}

During the evaluation of the syllabus, teachers found that, it contained a list of vocabulary, grammar, and functional items organised into units, with each level to be taught within a single semester, and it was based on a course book. According to the teachers, it seemed that the main purpose of the syllabus was that students learned the vocabulary and the grammar items included in the list.

The matter of the list of contents was reflected on the objectives, which according to the teachers were not clear. The lack of clear objectives was a matter that not only affected students, but teachers as well; as they were following an institutional syllabus which did not clearly indicate what and how teachers had to teach. The fact that the syllabus did not settle clear objectives, and it was only centred on language content gave rise to uncertainty among language teachers. The lack of clear objectives resulted in confusion and lack of security about teaching performance. The lack of clarity rose the possibility that teachers unilaterally decide about the outcome of the syllabus, as well as how to approach it. In addition to that the teaching methodology was not clearly stated either. In regard to evaluation, teachers also expressed that the syllabus did not include any particular element that allowed them to decide about the process of assessing outcomes.

The syllabus required learners to go through and consciously understand the rules underlying sentence construction, language learning is lineal and happens in sequence, starting with a first stage focus on input, teaching and output (Richards, and Rodgers, 1986). This type of syllabuses offers advantages and disadvantages. Some of the main advantages are that teachers find it familiar as they have probably learnt a language on the basis of this type of syllabus, and many language learners have been successful in learning a foreign language having been taught in the same way. Hedge (2000) emphasizes that focusing on form allows learners to pay attention to and to notice specific linguistic features; it also helps to associate learners' own knowledge with new knowledge.

Some of the disadvantages are that structure is not the core of communicative use, and therefore teaching and learning the language lineally is pointless (Lewis, 1996). Whereas Woodward (1993) and Scrivener (1994) argue that breaking the language up into parts avoids a more comprehensive coverage of the linguistic elements that shape the language. Other critical remarks are related to its emphasis on accuracy and correctness, as well as for its dissociation with real life communication (Willis, 1993). In addition, Nunan (1998) considers that the lineal model of language acquisition is inconsistent with what is observed as learners go about the process of acquiring another language.

The syllabus was not derived from school experience and experimentation; it was not in line with the reality of the school; as it had been directed at school teachers and could be realised in the form that was originally conceived by its designers. Teachers were told to follow a syllabus based on grammar, but they also had to be ready to prepare students to take an international exam in business English and this seemed to be confusing for the teachers. Both the use of the syllabus and the inclusion of content related to business English, with the aim of passing an international exam were decisions made by the university leadership, and did not include the opinion of the teachers who knew the classroom situations and learners' needs. This approach to syllabus deign is linked with a specialist approach defining from the top what is to be taught and teachers through instruction, implement the plan (Graves, 2008). Thus it was decided that the syllabus needed to change, following a SBCD approach.

\section{An Analysis of the Process of Syllabus Change on the Basis of NA Findings}

The participation of the teachers in the process of syllabus change was voluntary. However, the idea of conducting a project all by themselves under their own initiative and responsibility, without the intervention of a researcher seemed to be complicated; as issues such as time constrains, work load, motivation and accountability might seriously hinder practitioners to take initiative. Therefore, NA was conducted by the researcher. He collected, analysed and sorted the information, which was presented to the teachers in the form of tables and figures. The teachers' work consisted in analyisng and understanding the data shown in the tables and figures, and in using that information to change the original syllabus. 
The first piece of information shared with teachers was the information provided by the two employers interviewed. The data about the target situation started to define the characteristics of the syllabus. The data mainly revealed that students needed to develop specific linguistic skills. For example, students needed to read, and write all sort of information concerning internal communication of a company, as well as getting used to accents from different nationalities.

The evidence that the syllabus had to be more specific in terms of the aims and content, instead of being general, made a good impression to teachers concerning the process of change; as one of the problems they had identified in the original syllabus was the lack of specificity of the document. It was too general and teachers were uncertain about its aims.

The good impression was caused not only by the focus of the syllabus that was shifting towards a specific approach, but also by the fact that teachers were receiving authentic information provided by the target situation. This could help closing the gap between the students' language lacks, and the target language by revealing the language knowledge and skills students needed to effectively perform in the target situation (Gass, 2012).

Even when the teachers received information which indicated that the syllabus started to change, they were not quite certain of what to do with it. They realised that the syllabus had to be more specific, and the content had to promote the development of skills, but they were not sure about how to transform that information into learning outcomes or teaching content. Questions such as: what are we going to do with that information? What are we going to teach? Or what materials are we going to use? emerged. Although the researcher participated in the research, he tried not to get involved in that sort of decisions, to let teachers play a more predominant role to generate their own knowledge supported in practice and experience. This is vital as they know the classroom situations better than anybody and can thereby make a unique contribution to the success of the syllabus (Al-Daami and Stanley, 1998). Allowing teachers play a predominant role to generate knowledge based on practice and experience contributes to their professional development, giving them the role of curriculum developers, an idea that contrasts with the traditional top-down schema in which teachers play the role of implementers of the ideas of external curriculum developers and researchers, as generators of disciplinary knowledge, respectively (Ebbutt and Elliott (1985) in Keiny, 1993).

Concerning the results of the language tests teachers were presented the figures, together with a of descriptions of the language knowledge and skills students were tested on; the figures were crucial to understand language lacks students had, and the tables with the descriptions were also key to know what areas students had to improve.

The information provided to the participants was the product of an in depth analysis of the content of the language test. Each part of the test, listening, reading and writing contains sections and each section evaluates particular uses of language and vocabulary and specific skills. The form in which this information was presented to the teachers, allowed them easily identify those language aspects and skills students needed to improve. The information given to them was simple to understand and interpret that they could have used the descriptors as learning outcome statements. For instance one of the descriptions of the first part of the reading section stated: 'In this part, there is an emphasis on understanding short real-world notices, messages'. Thus, a learning outcome of the new syllabus could be: understanding short real-world notices, messages.

The detailed analysis the researcher did of the language test results was not a highly complex task. Any language teacher can do it. However, it is necessary to know the needs students have; otherwise it may not be easy to know what sort of analysis is suitable to do. That is why, it is essential to design syllabuses based on the school needs, and not only implement prescribed ones. Because, a school-based syllabus design process allows individuals to find information provided by people, who have knowledge and experience about the teaching context, this could help more successfully change things that need to be improved.

At this point of the project, teachers started to realise they needed different teaching resources from the ones they were using, because the syllabus and the materials they were using did not meet the new needs revealed by the data. They realised they needed teaching materials with specific purposes, which helped students to master those skills necessary to improve their performance in the test. They thought about two possibilities; on the one hand they could have collected materials from different sources, course books, internet, grammar books, which was basically the way they had collected the material for the original syllabus.

The other option teachers thought about was to follow a course book, which according to one teacher was a better option. One of the teachers searched different options concerning business English course books, and contacted the editorial staff. Teachers decided to adopt the series In Company edited by MacMillan, because the books fulfill the demands in terms of content, price and availability. 
The information about the students' beliefs complemented the data provided by the other two sources, the language test and the employers' opinion. Teachers found it more complex to understand the information of the questionnaire, because of the way it was presented, but once it was explained to them they started to realise the meaning. One of the first reactions about the information obtained through the questionnaire was upon the fact that students were motivated to learn. As described before, they expressed different types of motivation to learn English. This encouraged teachers to keep going with the idea of improving the syllabus.

The process of presenting, analyzing and discussing the information collected through the NA, is something that teachers had never done before. Perhaps they had collected data about the results of exams to sort students according to their English level, but they had neither analysed information provided by different sources such as students' beliefs, employers' opinions, as well as analysing the results of a language test with the aim of finding students' linguistic strengths and weaknesses, nor they had used it to design a syllabus.

It was a different approach teachers adopted to deal with the language syllabus. This occasion teachers were not given a completed syllabus to be implemented as conceived by syllabus designers. They dealt with authentic information based on school needs. This implied that they had to cope with situations they were not faced with, for example deciding about the learning outcomes of their courses, or thinking about the most suitable language content for their lessons. As stated before, they just implemented the syllabus given to them. By coping with new situations about their work environment, teachers grow professionally as they become more confident and knowledgeable, collecting and using evidence, and learning about their own learning (Furlong and Salisbury, 2005).

A key element of change in this process of syllabus improvement was NA, which proved to be a key element in syllabus design; as stated earlier it allowed both teachers and learners understand the language knowledge and skills needed to be included in the syllabus. It also helped define objectives, one thing that it was not clearly settled in the original syllabus. Additionally, NA provided information that allowed teachers to make informed decisions about the course of action of teaching and learning. It also helped to decide about the appropriate teaching methodology, as well as the most suitable assessment activities.

However, conducting NA can be challenging for classroom teachers, especially if they do not have experience in the field. For example, teachers should have a theoretical knowledge about the different NA approaches as well as the different data gathering techniques employed. This theoretical knowledge allows teachers make much more informed decisions about the sort of research methods to follow according to the context and the situation being researched. That knowledge can also allow teachers modify or adapt the original course of the investigation in the event that new challenges emerge. New challenges or issues could derive from data revealed by participants or unexpected events arising from the context. The more theoretical repertoire the researcher has in the field the better.

The data gathering stage is also challenging as it should provide adequate information to set the objectives of the course. Therefore, it is necessary to collect the type and quantity of data suitable to the aims of the process.

Another challenging moment of the process is the analysis and interpretation phase, as they saw data needs to be converted into information useful for decision making. One big issue concerning syllabus design is that teachers may not feel sufficiently skilled to do so; this was acknowledged by (Martin-Kniep and Uhrmacher, 1992; Shawer, 2010). Not all teachers feel capable of undertaking such a task; some believe that this activity should be carried out by people with specific expertise.

Another concern of the teachers may be related to the moment when they have to use the data to design the syllabus. Even when the data had been already analysed and put into tables and figures, teachers still had to interpret it, and to convert it into learning outcomes, teaching content, materials and strategies. Their lack of experience on analyzing and interpreting data to be used to feed the syllabus did not help them. They had been used to receiving the syllabus and implementing it, but they had never been involved in the process of designing.

Teachers also had not considered the opinions of other people because it had not been necessary to do so. They had never been asked to intervene in the design of a syllabus. They just followed the content of the original syllabus, but they had never considered the idea of involving other participants into the process of syllabus design, nor did they think about using the gathered data to feed into the syllabus. Following the content of a course book was a common practice.

Even when they recognized that including the wants and needs of different stakeholders into the syllabus was difficult, they believed not only that it was not impossible, but that it was something necessary to do.

Despite the difficulties and complexities concerning the process of using the gathered data to feed into the syllabus, language teachers agreed that it was something necessary to do, and also something which they felt more satisfied 
with and more committed to. They felt confident that, on the one hand the learners' language knowledge and skills were going to be improved, and on the other that what learners wished to learn was going to become part of the language syllabus. It goes without saying that they also sounded confident about integrating what was necessary in the learners' use of language.

Teachers had to arrive at crucial decisions about the proper way of making a careful and a detailed analysis of data to effectively incorporate it into the syllabuses. They had to select those key aspects that would meet the wants and needs of the great majority, that would be meaningful, and that would contribute to the improvement of learning. One thing the different stakeholders (the faculty, potential employer, learners) agreed on was the fact that learners should obtain a Business English Certificate. Thus, teachers decided to evaluate, adapt, and adopt a series of business English course books and a series of preparation course books for the Business English Certificate. Therefore, they decided to incorporate the content of the book series into their syllabuses. The main reasons why teachers adopted this course book were because it is skilled-based and it contains plenty of listening materials with content related to business. The book also contains several authentic tasks, as well as a lot of activities to learn vocabulary related to business.

Although the base of the new syllabus was the content of a course book, as in the case of the original syllabus, there are considerable differences between the content of one book and the other. For instance, the new approach is skilled-based, whilst the second is centred on a list of grammatical and vocabulary items. This is a key difference especially because the NA indicated that students had to develop linguistic skills, and not just learning grammatical aspects or vocabulary. Another vital difference is in regard to the materials, the new materials contained a lot of listening activities in which students listen to spoken English and extract factual information, and this was another need revealed throughout the NA. The new content also contains authentic information and tasks, which help students to be in contact with updated facts, as well as something what students will have to cope with eventually. Choosing a course book was a good choice for teachers as designing materials for a class demands a lot of time, experience, as well as knowledge and practise.

\section{Conclusion}

The findings of the present study demonstrate that language teachers engaged in a process of analysis and reflection are led to make decisions and changes based on local needs. They took part in different events during the course of a school year where they critically expressed their beliefs and opinions about the situation they were coping with. They incorporated data collected within their teaching context, which involved the opinions, wants, and needs of different stakeholders, into their language syllabuses, changing the original plans; setting clearer learning aims, incorporating new teaching content and methodology. Interviews reveal that practitioners were able to move beyond their routine teaching and critically reflect on their practice, which enhanced their understanding of educational context, making them more active participants of the improvement of the syllabus.

The major improvement was the process of syllabus design followed; since it showed a different way of designing and developing a syllabus, based on school needs rather than a syllabus prescribed from the top of an institution. Findings in this study report that the knowledge generated in this study by language teachers, was very significant as it was something they became aware of on their own, and not necessarily learned from theory. The knowledge they gained was based on inquiry and not by theoretical inputs by teaching experts (Elliot, 1989), and this was one of the main knowledge teachers gained. Teachers said that it was necessary to have moments of inquiry and reflection in order to discover important issues affecting the work environment. As a result of the enquiry teachers were able to address significant concerns related to the importance of collaborative work, stating that feedback provided good chances for them to learn, to share problems and concerns about specific situations of the class, and that it was better to address the problems as a group.

Despite the volume of claims presented above, findings reveal that not to know about NA could hinder the gathering of data, as teachers might not feel fully competent to carry out the work. Also, not to have the capacity to processing data may lead to losing its importance. In addition to this, teachers need to develop the skills to interpret the data and to transform it into teaching goals, content, and activities. The lack of available time and the heavy workload are also challenges that teachers could face if they conduct NA by their own.

\section{References}

Ahmad, A., \& Sajjad, P. (2011). Role of local constraints in the failure of Western approaches to ELT. Procedia 
Social and Behavioral Sciences, 15, 1766-1770. https://doi.org/10.1016/j.sbspro.2011.03.366

Al-Daami, K. K., \& Stanley, J. W. (1998). The contribution of primary school teachers to curriculum planning and development in Iraq. Curriculum Journal, 9(3), 357-376. http://dx.doi.org/10.1080/0958517970090308

Ariogul, S., Unal, D C., \& Onursal, I. (2009). Foreign language learner's beliefs about language learning: a study on Turkish university students. Procedia Social and Behavioral Sciences, 1, 1500-1506. https://doi.org/10.1016/j.sbspro.2009.01.265

Cohen, L., Manion, L., \& Morrison, K. (2011). Research methods in education (7th ed.). London and New York: Routledge.

Connelly, F. M., \& Ben-Perez, B. (1980). Teachers role in the using and doing of research and curriculum development. Journal of Curriculum Studies, 12(2), 95-107.

Cowling, J. D. (2007). Needs analysis: planning a syllabus for a series of intensive workplace courses at a leading Japanese company. English for Specific Purposes, 26, 426-442. https://doi.org/10.1016/j.esp.2006.10.003

Davies, P. (2008). ELT in Mexican higher education should be mainly ESP, not EGP. MEXTESOL Journal, 32(1), 80-89.

Davies, P. (2009). Strategic management of ELT in public educational systems: trying to reduce failure, increase success. The Electronic Journal for English as a Second Language, 13(3). Retrieved from http://www.tesl-ej.org/wordpress/issues/volume13/ej51/ej51a2/

Dörnyei, Z. (2007). Research methods in applied linguistics. Quantitative, qualitative and mixed methodologies. Oxford: OUP.

Ebbutt, D., \& Elliott, J. (1985). Why school teachers do research? In D. Ebbutt and Elliott (Eds.), Issues in teaching for understanding. Cambridge: CUP.

Elliot, J. (1989). Academic and action research: the training workshop as an exercise in ideological deconstruction. Presented at the Annual Meeting of the American Educational Research Association, San Francisco CA. Retrieved from http://files.eric.ed.gov/fulltext/ED307715.pdf

Furlong, J., \& Salisbury, J. (2005). Best practice research scholarships: an evaluation. Research Papers in Education, 20(1), 45-83. http://dx.doi.org/10.1080/0267152052000341336

Gass, J. (2012). Needs analysis and situational analysis: designing an ESP curriculum for Thai nurses. English for Specific Purposes, 12(36), 1-21.

Graves, K. (1996). A framework of course development process. In Teachers as course developers. Cambridge: CUP.

Holliday, A. (1994a). Appropriate methodology and social context. Cambridge: CUP.

Holliday, A. (1995). Assessing language needs within an institutional context: An ethnographic approach. English for Specific Purposes, 14(2), 115-126. https://doi.org/10.1016/0889-4906(95)00006-D

Hedge, T. (2000). Teaching and Learning in the Language Classroom. Oxford: OUP.

Keiny, S. (1993). School-based curriculum development as a process of teachers' professional development. Educational Action Research, 1(1), 65-93. https://doi.org/10.1080/0965079930010105

Le Ha, P. (2004). University classroom in Vietnam: contesting the stereotypes. English Language Teaching Journal, 58(1), 50-57. https://doi.org/10.1093/elt/58.1.50

Lewis, M. (1996). Implications of the lexical view of language. In J. Willis (Ed.), Challenge and change in language teaching. Oxford: Heinemann.

Long, M H. (2005). Second Language Needs Analysis. Cambridge: CUP.

Marsh, C., Day, C., Hannay, L., \& McCutcheon, L. (1990). Reconceptualizing school-based curriculum development. London: Falmer Press.

Marsh, C. J. (2009). Key concepts for understanding curriculum (4th ed.). London and New York: Routledge Taylor and Francis Group.

Martin-Kniep, G., \& Uhrmacher, B. (1992). Teachers as curriculum developers. Curriculum Studies, 24(3), 261-271.

Mori, Y. (1999). Epistemological beliefs and language learning beliefs: what do language learners believe about their learning. Language Learning, 49(3), 377-415. https://doi.org/10.1111/0023-8333.00094 
Nunan, D. (1998). Teaching grammar in context. English Language Teaching Journal, 52(2).

Nunan, D. (2003). The impact of English as a global language on educational policies and practices in the Asian-Pacific region. TESOL QUARTERLY, 37(4). https://doi.org/10.2307/3588214

O'Sullivan, M. (2002). Reform implementation and the realities within which teachers work: a Namibian case study. Compare, 32(2), 219-237. http://dx.doi.org/10.1080/03057920220143192

Prince, D. (1984). Workplace English: approach and analysis. The ESP Journal, 3(2), 109-116.

Richards, J. C., \& Rodgers T, S. (1986). Approaches and methods in language teaching. Cambridge: CUP. https://doi.org/10.1016/0272-2380(84)90021-0

SEP. (2010). National English program in basic education second language: English. Retrieved from http://www.sepbcs.gob.mx/Educacion\%20Basica/Programa_Ingles/Materiales_A/Ciclo\%203/Guia\%20de\%20re -nivelacion\%20ingles.pdf

Scrivener, J. (1994). PPP and after. The Teacher Trainer, 8(1), 15-16.

Shawer, S. F. (2010). Classroom-level curriculum development: EFL teachers as curriculum-developers, curriculum-makers and curriculum-transmitters. Teaching and Teacher Education, 26(2), 173-184. https://doi.org/10.1016/j.tate.2009.03.015

Srabua, B. (2007). An analysis of needs and problems in the use of English for occupational purposes of hotels PR officers in Bangkok. Kasetsart University, Thailand. Retrieved from http://research.rdi.ku.ac.th/world/showItem.php?itemID=82019

Trinder, R. (2013). Business students' beliefs about language in a university context. English for Specific Purposes, 32, 1-11. https://doi.org/10.1016/j.esp.2012.06.003

UNESCO. (2009). 2009 World Conference on Higher Education: The New Dynamics of Higher Education and Research For Societal Change and Development. Retrieved from http://www.uis.unesco.org/Library/Documents/trends-global-higher-education-2009-world-conference-en.pdf

Skilbeck, M. (1984). Reading school based curriculum development. London: Harper and Row.

Stenhouse, L. (1975). An introduction to curriculum research and development. London: Heinemann.

Willis, J. (1993). Preaching what we practice - training what we teach: Task-based language learning as an alternative to P.P. P. The Teacher Trainer, 8(1), 17-20.

Woodward, T. (1993). Changing the basis of pre-service TFL training the UK. IATEFL TT SIG Newsletter, 13, 3-5.

Wozniak, S. (2010). Language needs analysis from a perspective of international professional mobility: the case of French mountain guides. English for Specific Purposes, 29, 243-252. https://doi.org/10.1016/j.esp.2010.06.001 